\title{
The first Turkish illustrated surgical textbook 'Cerrahiyetü'l-Haniyye'
}

\author{
İlhan Bahși ${ }^{1}$ (D) Ayșe Bahși ${ }^{2}$ - Murat Çetkin ${ }^{1}$ • Mehmet Akif Çeçen ${ }^{3}$
}

Received: 11 July 2016 / Accepted: 14 July 2016/Published online: 3 August 2016

(C) Springer-Verlag Berlin Heidelberg 2016

\section{Introduction}

The work named Cerrahiyetü'l-Haniyye which was written by Şerafettin Sabuncuoğlu (1385-1470?) is quite important for history of medicine [1]. Famous Turkish doctor Sabuncuoğlu (Fig. 1) served as a clinician, trainer, and researcher for 14 years in Amasya Darussifa [1-3]. Sabuncuoğlu wrote three books which are named as Terceme-i Akrabadin, Mücerrebname, and Cerrahiyetü'l-Haniyye [1,2]. In Cerrahiyetü'l-Haniyye, he explained various diseases and also treatment of these diseases [2]. This book is known as first handwritten surgical book in the Turkish and the Islamic World which reflects knowledge and skills of doctors who lived in Anatolia [1, 4]. The book also depicts some of the treatment implemented by doctors with the help of drawing miniature $[1,4]$. The example of this, a surgery procedure performed on the posterior head region, was depicted in Fig. 2 and cover fgure. Treatment process of a patient who

İlhan Bahși

dr.ilhanbahsi@gmail.com

Ayșe Bahși

dr.aysebahsi@gmail.com

$\triangle$ Mehmet Akif Çeçen

akifcecen@gmail.com

Murat Çetkin

muratcetkin@hotmail.com

1 Department of Anatomy, Faculty of Medicine, Gaziantep University, TR-27310 Gaziantep, Turkey

2 Department of Physical Medicine and Rehabilitation, Faculty of Medicine, Gaziantep University, TR-27310 Gaziantep, Turkey

3 Department of Turkish Language Education, Faculty of Education, İnönü University, Malatya, Turkey had cold and was not treated with the drug was explained in the statement part of this miniature. In this treatment, the artery located between two external ear (occipital artery) was cut and some blood was shed (Fig. 2 and cover figure). Then, the ointment was applied on the cutted region to the avoid for inflammation on the surgery site and wound site was closed [1]. In Cerrahiyetü'l-Haniyye, there are pictures of instruments which are used as treatment. These miniature and pictures of instruments were evaluated on many publications $[1-3,5-7]$, and this situation shows how valuable the book is.

Cerrahiyetü'l-Haniyye was written in Turkish language with the use of Arabic alphabets [1,2]. Written in Turkish is one of the important features of the book. Three different editions are known nowadays. Two of the books are in Istanbul (in Fatih Millet Library and in Library of Medicine History Department, Faculty of Medicine, University of İstanbul) and one of them is in Paris (Bibliothe'que Nationale) $[1,8]$. The book has been introduced again in the beginning of the twentieth century to the world of science. Although this information shows variety in different articles, the first introducer was Ali Canip by the writing in the journal of Hayat Mecmuas in 1927 [1, 2, 9]. It is known that Cerrahiyetü'l-Haniyye substantially similar to the book called et-Tasrif which was written by Arap author Zehravi lived in tenth century [2]. Uzel pointed out that there were 137 differences between these two books [1]. In Cerrahiyetü'l-Haniyye, there are general surgery, pediatric surgery, plastic surgery, orthopedic surgery, thoracic surgery, urology, obstetrics and gynecology sections [1, 2, 5-13].

Keskinbora [4] reported that although it has been more than 550 years, some part of the methods are still using. Explaining diseases and treatments by the help of figure and miniature and also his efforts of transferring this information to doctors show that Șeraffettin Sabuncuoğlu and his works have an important place in history of medicine. 


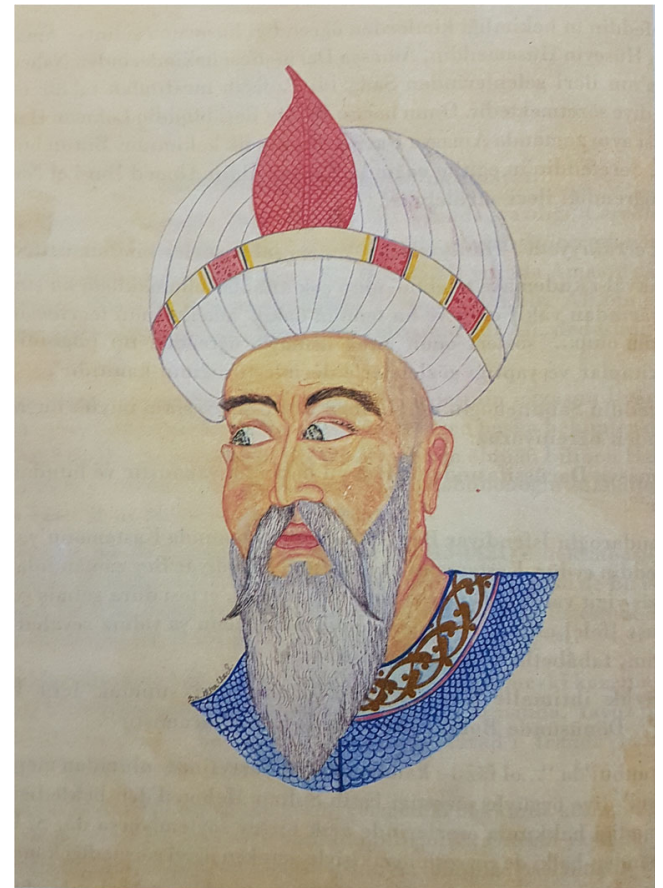

Fig. 1 Șerafeddin Sabuncuoğlu (1385-1470?). Drawn after Cerrahiyyetü'l Haniye by Dr. Uzel [1]

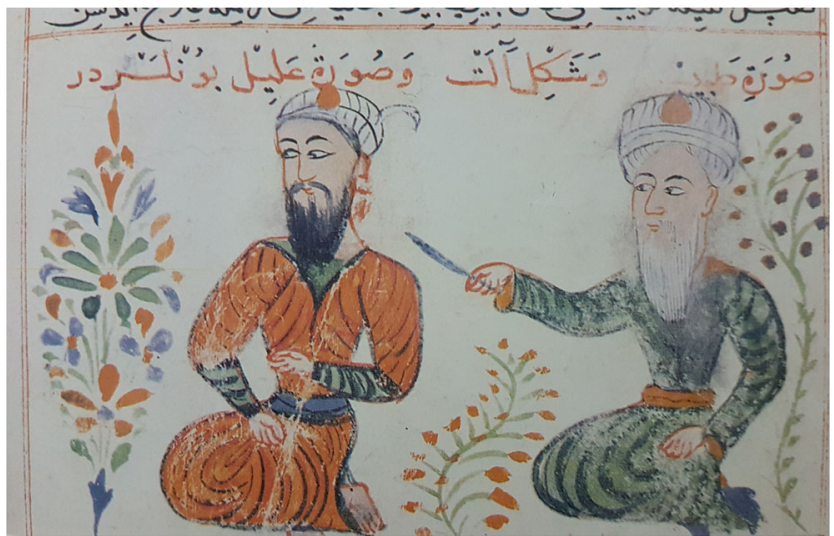

Fig. 2 and cover figure. The drawing about the incision of occipital arteries on the posterior head in the handwritten [1]

\section{Compliance with ethical standards}

Conflict of interests The authors declare that there is no conflict of interest.

\section{References}

1. Uzel I (1992) Cerrahiyetü'l-Haniyye I, 1st ed. (in Turkish). Ankara, Türk Tarih Kurumu Yayınları (Turkish Historical Society), Ankara

2. Acar HV (2015) Articles from Turkey in SCI-E journals, in the 550th years of Cerrahiyetü'l-Haniyye. Lokman Hekim Journal 5: $37-44$

3. Turgut M (2007) Illustrations of neurosurgical techniques in early period of ottoman empire by Şerefeddin Sabuncuoğlu. Acta Neurochir 149:1063-1069

4. Keskinbora HK (2013) Șerefeddin Sabuncuoğlu'nun Cerrahiyet-ül Haniye Kitabında Göz Hastalıkları Konuları. Lokman Hekim Journal 3:16-24

5. Elmac1 I (2000) Color illustrations and neurosurgical techniques of Serefeddin Sabuncuoglu in the 15th century. Neurosurgery 47:951955

6. Kafali H, Aksoy S, Atmaca F, San I (2002) Colored illustrations of obstetrics manipulations and instrumentation techniques of a Turkish surgeon Serafeddin Sabuncuoglu in the 15th century. European Journal of Obstetrics \& Gynecology and Reproductive Biology 105:197-202

7. Kadıŏlu NS, Ögenler O, Uzel I (2011) Șerefeddin Sabuncuoğlu's drawings of gyneco-obstetric instruments. Turkish Journal of Medical Sciences 41:1-5

8. Bademci G, Batay F, Sabuncuoglu H (2005) First detailed description of axial traction techniques by Serefeddin Sabuncuoglu in the 15th century. Eur Spine J 14:810-812

9. Aygen G, Karasu A, Ofluoglu AE, Pait G, Toplamaoglu H (2009) The first Anatolian contribution to treatment of sciatica by Serefeddin Sabuncuoglu in the 15th century. Surg Neurol 71:130-133

10. Senayli A, Aksu M, Atalar M (2014) A circumcision method in an old surgical textbook (Cerrahiyyetul Haniyye): reminding of a forgotten procedure. Urol J 11:1731-1734

11. San I, Oguz H, Kafali H (2005) Colored illustrations of pediatric otorhinolaryngologic surgical techniques of a Turkish surgeon, Serefeddin Sabuncuoglu, in the 15th century. Int J Pediatr Otorhinolaryngol 69:885-891

12. Turgut $M$ (2008) Surgical instruments utilized in foetal hydrocephalus to prevent the mother's death at the time of Serefeddin Sabuncuoğlu (1385-1468 ad). Childs Nerv Syst 24:783-783

13. Hiçdönmez T, Özek MM (2006) Hydrocephalus in Sabuncuoğlu's textbook of surgery: Cerrahiyyet'ul Haniyye. Childs Nerv Syst 22: $545-546$ 